\title{
Effectiveness of native arbuscular mycorrhizal consortia on the growth of Agave inaequidens
}

\author{
Evangelina Esmeralda Quiñones-Aguilar ${ }^{1}$, Amelia Cristina Montoya-Martínez ${ }^{1,2}$, Gabriel \\ Rincón-Enriquez ${ }^{1}$, Philippe Lobit ${ }^{2}$, Luis López-Pérez ${ }^{2 *}$
}

${ }^{1}$ Centro de Investigación y Asistencia en Tecnología y Diseño del Estado de Jalisco, A.C. (CIATEJ). Guadalajara, Jalisco. CP. 44270. México. ${ }^{2}$ Instituto de Investigaciones Agropecuarias y Forestales, Universidad Michoacana de San Nicolás de Hidalgo. Tarímbaro, Michoacán. CP. 58880. México.

*Corresponding autor: lexquilax@yahoo.com.mx

\begin{abstract}
The aim of this study was to evaluate the effect of eight native consortia of arbuscular mycorrhizal fungi (AMF), a commercial strain and a control without AMF on the growth of Agave inaequidens. Agave seedlings were inoculated and kept under greenhouse conditions for 300 days. At 90, 180 and 270 days after inoculation, the number of leaves and plant height were recorded; at the end of the experiment, fresh and dry weight, head (also known as heart or piña) diameter, leaf area and root length and volume were recorded. The percentage of mycorrhizal colonization, the relative mycorrhizal dependency index and the Dickson index were also calculated. Results showed a growth-promoting effect on agave plants when inoculated with native consortia, namely Barranca de las nueces, El Limón, Agua Dulce and Huizachal, compared to the control. Colonization values were high (45\%) and similar to those reported in other studies with agaves. Plants inoculated with the Huichazal consortium obtained the highest Dickson index (9.6). It can be concluded that native consortia are a feasible alternative for use as growth promoters in Agave inaequidens and that they can be a good option as biofertilizer sunder nursery conditions.
\end{abstract}

Keywords: Agave mezcal, consortium, mycorrhiza, bio-fertilizer, maguey, inoculum

\section{Introduction}

Mycorrhizal fungi are obligate symbiotic microorganisms that colonize the root of more than $80 \%$ of plant species (Smith and Read, 1997). It is known that this symbiotic relationship promotes the growth of host plants and that the roots of the plants can be colonized by more than one AMF species. It is also reported that there is no plant-fungus specificity, but the effect that the fungus has on its host can be different, promoting growth, increasing nutrient and water uptake capacity, or inducing resistance to biotic or abiotic 
stresses, among others (Hodge, 2000), so it can be stated that there is a differential effectiveness (Smith and Gianinazi-Pearson, 1988; Robles-Martínez et al., 2013). On the other hand, Gavito and Varela (1995) and Bashan et al. (2000) mention that inocula consisting of more than one species of AMF provide a greater benefit in their hosts. It is also known that native mycorrhizal consortia are usually more effective than those composed of exotic species or a single species (Bashan et al., 2000; Pérez-Solís, 2001). The reason for this is that the fungus is adapted to certain specific environmental conditions and its introduction into different environments can cause maladjustments to the medium (Rillingand Mummey, 2006). Hence, when assessing the effective potential of AMF consortia, it is important to use those extracted from sites where the host species grows, as it will ensure that the species have greater adaptability to the natural conditions where the plant species grows or have greater effectiveness or infectivity with the plant species.

There are several studies where the effectiveness of native consortia on plant growth in different species is demonstrated (Trejo et al., 2011; Carreón-Abud et al., 2015). In the case of agave, there are reports on the promoter effect of AMF (Cui and Nobel, 1992; Pimienta-Barrios et al., 2009; Robles-Martínez et al., 2013); however,these studies used only non-native inocula or monospecific inocula. Conversely, RoblesMartínez et al. (2013), working with six native AMF consortia and Glomus intraradices in bulbils and tillers of Agave angustofolia, reported a differential response in height, leaf production, biomass and root growth in response to inoculation and conclude that the agaves had better functional compatibility with the native consortia than with the introduced species. On the other hand, it is known that there is a large number of mycorrhizal fungi in the rhizosphere of agaves (Ochoa-Meza et al., 2009; Rincón-Enríquez et al., 2012; Carballar-Hernández et al., 2013; Hernández-Morales et al., 2014; Reyes-Tena et al., 2015), so it is believed that this species is being colonized by more than one species and that there may be a preference for a particular species or a differential effectiveness. However, for Agave inaequidens there have been no reports of AMF species associated with its rhizosphere, or the effect that they provide.

Agave inaequidens Koch is one of the species found naturally or in plantations in central Mexico. It is economically important because it is the raw material for the production of mezcal (Figueredo et al., 2015).Within the municipalities included in the denomination of origin of mezcal in the state of Michoacán, Mexico, this species is one of the most used and appreciated for the quality of its distillate. Currently, agave producers in this region are unaware of the use and potential of AMF as growth promoters, so the aim of this work was to evaluate the effect of eight native AMF consortia and a monosporic inoculum (Glomussp) on the growth of Agave inaequidens Koch under greenhouse conditions.

\section{Materials and Methods}

\subsection{AMF inocula.}

Eight native mycorrhizal consortia and a commercial inoculum $\left(\right.$ INIFAP $^{\circledR}$ ) were used. The consortia came from soils with Agave cupreata plantations in the state of Michoacán, and were named according to the collection site: El Huizachal (EH), Las Campesinas(LC), Carlos Rojas (CR), Paso Ancho (PA), El limón (EL), Cerro del Metate (CM), Barranca de las Nueces (BN), and Agua Dulce (AD). The inocula were previously propagated for 12 months in trap pots in a greenhouse. Consortia were composed of different AMF species, finding a total of 40 species in 
13 genera, 9 families and 3 orders (Rincón-Enríquez et al., 2012). Each consortium contained between four to six species, with the most abundant in each mycorrhizal consortium being as follows: CM: Glomus glomerulatum, BN: Acaulospora excavata, PA: Acaulospora delicata, CR, EL y EH: Glomus deserticola, LC: Acaulosporas crobiculata, and AD: Claroideoglomus claroideum (Reyes-Tena et al., 2015).

\subsection{Plant material}

Agave inaequidens seeds were disinfected with a $6 \%$ active chlorine solution for $10 \mathrm{~min}$ and then washed with distilled water three times for $5 \mathrm{~min}$. Later, they began to germinate in plastic trays with peat moss (previously sterilized) under low light and ambient humidity conditions. The substrate was kept hydrated at all times. Four months after planting, the seedlings were transplanted and had an average fresh weight of $2.3 \mathrm{~g}, 3$ true leaves and $3 \mathrm{~cm}$ in height.

\subsection{Inoculation}

Agave inaequidens seedlings were transplanted into black polyethylene bags with $1.5 \mathrm{~kg}$ of a mixture of previously-sterilized sand and soil $(1: 1 \mathrm{v} / \mathrm{v})$ as growth medium. A cavity was made in the center of the bag where the seedling was placed and at transplanting the inoculation of the different mycorrhizal consortia was made directly to the root system. From each AMF consortium, the necessary grams to inoculate with 80 spores were taken and for the treatment without AMF, $10 \mathrm{~g}$ of sterile sand were inoculated per seedling. Once the inoculation was done, the seedlings were kept for 300 days under greenhouse conditions and watered with distilled water whenever necessary to maintain the substrate at field capacity. Ten treatments were generated and replicated five times and the ex- perimental unit was an agave plant; a completely randomized block experimental design was used.

\subsection{Plant growth variables and mycorrhization}

Samplings were carried out at 90, 180, 270 and 300 days after inoculation (dai), where plant height and number ofcompletely unfolded leaves were recorded. At the end of the trial (300 dai), the volume of the foliage and root was obtained by the water displacement technique using a graduated 1-L cylinder; head diameter was measured using a digital Vernier caliper, the length of the longest root was measured manually with a tape measure, and leaf area was measured with a digital planimeter (LICOR LI-3100). For shoot and root fresh weight (SFW and RFW, respectively), an analytical balance (Mettler Toledo AT200) was used; then the samples were dried in an oven at $60^{\circ} \mathrm{C}$ to constant weight and finally total dry weight (TDW) was recorded. Mycorrhizal colonization was determined by the root clearing and staining technique of Hayman and Phillips (1970), with slight modifications. Subsequently, the percentage of mycorrhizal colonization was determined with the method described by McGonigle et al. (1990). The relative mycorrhizal dependency index (RMDI) proposed by Plenchette et al. (1983) was calculated, and for plant quality the Dickson index (Dickson et al., 1960) was used.

\subsection{Statistical analysis}

Data were subjected to a one-way analysis of variance and Tukey's range test, both at a significance level of $P \leq 0.05$. Data were processed in SPSS 14.0 (SPSS Inc., Chicago, IL, USA) statistical software. 


\section{Results}

For leaf production dynamics, a significant statistical difference (Tukey, $p \leq 0.05$ ) among treatments from 90 days after inoculation (dai) was observed. From this date, treatments where AMF were inoculated had the highest number of unfolded leaves and maintained this significant trend until the end of the experiment. After 300 dai, treatments that had the highest number of leaves were the $\mathrm{BN}, \mathrm{EH}, \mathrm{CM}$ and $\mathrm{AD}$ consortia, being statistically superior to non-inoculated plants and averaging between 4 and 10 more leaves than the treatment inoculated with the commercial INIFAP consortium and without AMF respectively (Figure 1).

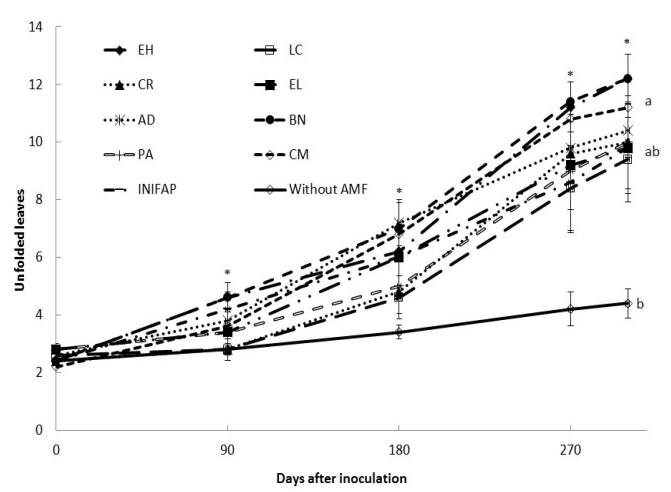

Figure 1. Effect of inoculation with AMF on leaf production dynamics of Agave inaequidens plants. EH, El Huichazal; CR, Carlos Rojas; AD, Agua Dulce; PA, Paso Ancho; LC, Las Campesinas; EL, El Limón; BN, Barranca de las Nueces; CM, Cerro del Metate. ${ }^{*}$ and lines with different letters indicate significant (Tukey, $p \leq 0.05$ ), between treatments in this date.

In the case of plant height dynamics, the same trend observed in unfolded leaves from 90 dai was found. From this date, plants inoculated with the
AD consortium were taller and reached a height of $10 \mathrm{~cm}$ at 300 dai, being almost five times greater than the height obtained in plants not inoculated with AMF. Unlike the variable unfolded leaves, for plant height a greater difference among treatments was observed during the trial period (Figure 2).

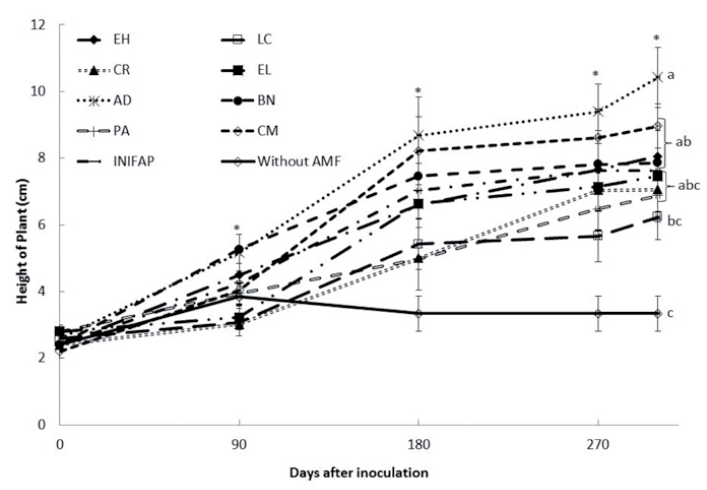

Figure 2. Effect of inoculation with AMF on height of Agave inaequidens plants.EH, El Huichazal; CR, Carlos Rojas; AD, Agua Dulce; PA, Paso Ancho; LC, Las Campesinas; EL, El Limón; BN, Barranca de las Nueces; CM, Cerro del Metate. ${ }^{*}$ and lines with different letters indicate significant (Tukey, $p \leq 0.05$ ), between treatments in this date.

Likewise, significant statistical differences (Tukey, $p \leq 0.05$ ) among the different mycorrhizal consortia and the treatment without AMF were found for all variables assessed at 300 dai, except for root length. However, it was observed that in the treatments inoculated with AMF, root length was longer (up to two times more) compared to plants without AMF, in particular with the EL consortium (Table 1). 
Table 1. Effect of Arbuscular Mycorrhizal Fungi inoculation on Agave inaequidens growth at 300 days after inoculation.

\begin{tabular}{|c|c|c|c|c|c|c|c|c|c|}
\hline \multirow[t]{2}{*}{ Inocula } & \multirow[t]{2}{*}{ LFW } & \multirow{2}{*}{$\begin{array}{c}\text { RFW } \\
\\
(\mathrm{g})\end{array}$} & \multirow[t]{2}{*}{ TFB } & \multicolumn{2}{|c|}{$\begin{array}{l}\text { Volume } \\
\left(\mathrm{cm}^{3}\right)\end{array}$} & \multirow{2}{*}{$\begin{array}{l}\text { Root } \\
\text { Length } \\
\text { (cm) }\end{array}$} & \multirow{2}{*}{$\begin{array}{c}\text { Head } \\
\text { Diameter } \\
\text { (mm) }\end{array}$} & \multirow[t]{2}{*}{ RMDI } & \multirow[t]{2}{*}{ QDI } \\
\hline & & & & Root & Leaf & & & & \\
\hline EH & $62.39 \mathrm{ab}$ & $22.81 \mathrm{ab}$ & $85.62 \mathrm{ab}$ & $16.66 \mathrm{ab}$ & $76.60 \mathrm{ab}$ & $32.76 \mathrm{a}$ & $28.39 \mathrm{a}$ & $94.05 \mathrm{a}$ & 9.65 \\
\hline LC & $71.63 \mathrm{ab}$ & $12.38 \mathrm{~b}$ & $83.76 \mathrm{ab}$ & $9.50 \mathrm{ab}$ & $72.50 \mathrm{ab}$ & $31.02 \mathrm{a}$ & $22.30 \mathrm{ab}$ & $82.61 \mathrm{a}$ & 3.90 \\
\hline CR & $55.80 \mathrm{ab}$ & $2.48 \mathrm{~b}$ & $57.79 \mathrm{ab}$ & $5.25 \mathrm{~b}$ & $56.80 \mathrm{ab}$ & $28.46 \mathrm{a}$ & $24.12 \mathrm{ab}$ & $84.35 \mathrm{a}$ & 2.34 \\
\hline EL & $101.62 \mathrm{a}$ & $10.27 \mathrm{~b}$ & $111.13 \mathrm{a}$ & $16.66 \mathrm{ab}$ & $121.25 \mathrm{a}$ & $37.17 \mathrm{a}$ & $30.43 \mathrm{a}$ & $95.93 \mathrm{a}$ & 6.09 \\
\hline $\mathrm{AD}$ & $96.38 \mathrm{a}$ & $17.80 \mathrm{~b}$ & $114.18 \mathrm{a}$ & $20.00 \mathrm{a}$ & $81.00 \mathrm{ab}$ & $30.46 \mathrm{a}$ & $28.47 \mathrm{a}$ & $93.92 \mathrm{a}$ & 3.92 \\
\hline $\mathrm{BN}$ & $95.04 \mathrm{a}$ & $43.80 \mathrm{a}$ & $138.84 \mathrm{a}$ & $6.50 \mathrm{ab}$ & $87.50 \mathrm{a}$ & $31.65 \mathrm{a}$ & $28.14 \mathrm{a}$ & $93.18 \mathrm{a}$ & 3.86 \\
\hline PA & $58.20 \mathrm{ab}$ & $5.69 \mathrm{~b}$ & $63.89 \mathrm{ab}$ & $5.50 \mathrm{~b}$ & $72.33 \mathrm{ab}$ & $26.22 \mathrm{a}$ & $23.03 \mathrm{ab}$ & $79.29 \mathrm{a}$ & 4.06 \\
\hline $\mathrm{CM}$ & 88.72 a & $7.10 \mathrm{~b}$ & $95.82 \mathrm{a}$ & $15.50 \mathrm{ab}$ & $89.00 \mathrm{a}$ & $34.54 \mathrm{a}$ & $29.22 \mathrm{a}$ & $93.06 \mathrm{a}$ & 3.77 \\
\hline INIFAP & $68.18 \mathrm{ab}$ & $16.89 \mathrm{~b}$ & $85.07 \mathrm{ab}$ & $7.00 \mathrm{ab}$ & $85.00 \mathrm{ab}$ & $32.40 \mathrm{a}$ & $24.04 \mathrm{ab}$ & $79.30 \mathrm{a}$ & 4.1 \\
\hline $\begin{array}{l}\text { Without } \\
\text { AMF }\end{array}$ & $4.64 \mathrm{~b}$ & $0.72 \mathrm{~b}$ & $5.36 \mathrm{~b}$ & $3.00 \mathrm{~b}$ & $6.60 \mathrm{~b}$ & $18.2 \mathrm{a}$ & $11.04 \mathrm{~b}$ & - & 0.12 \\
\hline
\end{tabular}

LFW, Leaf FreshWeight; RFW, Root Fresh Weight; TFB, Total Fresh Biomass; RMDI, Relative Mycorrhizal Dependency Index; QDI, Quality Dickson Index; EH, El Huichazal; CR, Carlos Rojas; AD, Agua Dulce; PA, Paso Ancho; LC, Las Campesinas; EL, El Limón; BN, Barranca de las Nueces; CM, Cerro del Metate. Means (n=5) with same letters by column are statistically equals (Tukey, $p \leq 0.05$ ).

Regarding fresh biomass, a high response to inoculation with AMF relative to the treatment without AMF was found, being for some variables the greatest response observed when inoculated with a native consortium. The EL, AD and BN inocula obtained the biggest gain in leaf fresh weight, averaging up to 22 times higher than in plants without AMF. Plants inoculated with the INIFAP consortium were statistically equal to all treatments. In the case of RFW, greater variability in the results was found; however, it was observed that the roots of agaves inoculated with AMF had greater weight. In those plants inocu- lated with the BN consortium, their roots were statistically superior to those of the other treatments, except for $\mathrm{EH}$, and were 60 times higher than the roots of agaves without AMF. Regarding TFB, the trend recorded in LFW and RFW, where the AMF-inoculated agaves attained the highest fresh weights, was found. In this case, the agaves that were inoculated with the $\mathrm{BN}, \mathrm{AD}$ and EL consortia exceeded $100 \mathrm{~g}$ total fresh weight and were 26, 21 and 20 times higher, respectively, than the agaves without AMF (Table 1). Head diameter showed significant increases (Tukey, $p \leq 0.05)$ in the AMF-inoculated treatments. The EL, 
$\mathrm{EH}, \mathrm{AD}, \mathrm{BN}$ and $\mathrm{CM}$ consortia attained the largest diameters, but in the EL consortium the largest head diameter was reached, being almost three times larger than in those agaves where no AMF were applied. The remaining consortia, although they were statistically equal to the treatment without AMF, showed two fold or greater increases in head diameter (Table 1).

For the variable root volume, plants with the $\mathrm{AD}$ inoculum obtained the largest root volume, being almost seven times higher than that of plants without AMF, which obtained the lowest value. The EH, EL and CM consortia attained an average root volume of $15 \mathrm{~cm}^{3}$, but it proved to be statistically equal to the treatment without AMF. However, despite this, the root volume attained with these consortia was almost five times greater than that obtained in plants without AMF. In the case of leaf volume, plants with the El consortium obtained the highest value, followed by the $\mathrm{CM}$ and $\mathrm{BN}$ consortia. The remaining consortia obtained a leaf volume of between 70 and $85 \mathrm{~cm}^{3}$. The treatment without AMF had the lowest leaf volume, being 18 times lower than the volume reached with the EL consortium (Table 1). The increase in total volume of AMF-inoculated plants was far superior to that reached in non-inoculated plants. Plants with the EL consortia showed the highest increase in total volume with $1200 \%$, compared to plants without AMF. The other consortia were statistically different from the treatment without AMF and had increases greater than $1000 \%$, except for the $\mathrm{CR}, \mathrm{AD}$ and PA consortia, which were statistically equal to the treatment without AMF. Despite this, on average they had an increase of between 600 and 900\% (Figure 3A). For leaf area, treatments inoculated with the EL, AD, BN CM and LC consortia were statistically equal and attained the largest leaf area with an average of 275 $\mathrm{cm}^{2}$, which is 10 times larger than that obtained in the treatment without AMF. The CR inoculum proved to be statistically equal to the treatment without $\mathrm{AMF}$, which obtained the smallest leaf area (Figure 3B).
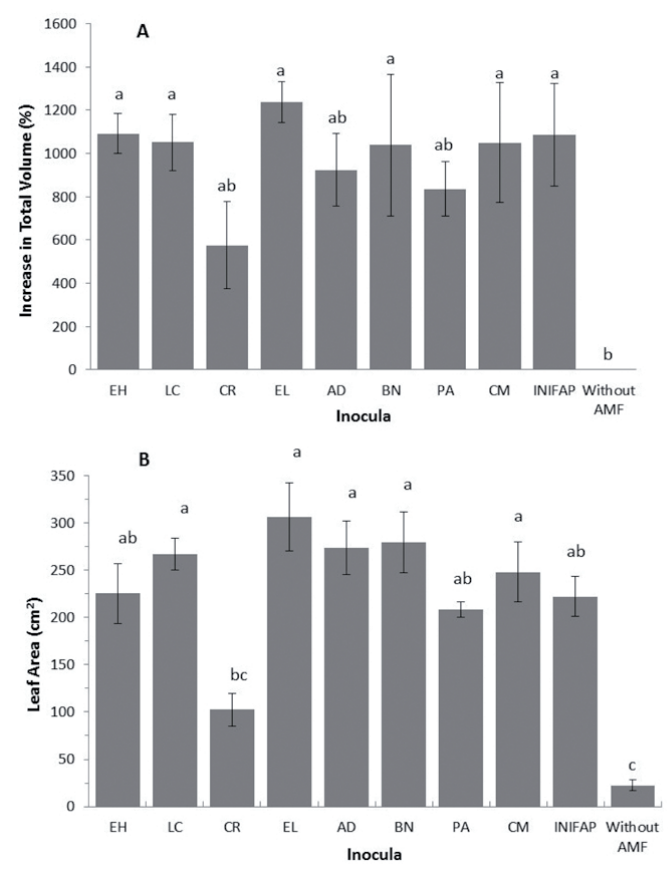

Figure 3. Increase in total volume (A) on Agave inaequidens plants inoculated with different AMF, respect to plants without $\mathrm{AMF}$ and leaf area (B) at 300 days after inoculation. EH, El Huichazal; CR, Carlos Rojas; AD, Agua Dulce; PA, Paso Ancho; LC, Las Campesinas; EL, El Limón; BN, Barranca de las Nueces; CM, Cerro del Metate. Columns with the same letter are statistically equals (Tukey, $p \leq 0.05$ ).

The total dry biomass showed a significant increase (Tukey, $p \leq 0.05$ ) when agave plants were inoculated with AMF. An increase in total dry weight exceeding $500 \%$ was obtained with all the mycorrhizal consortia with respect to the plants without AMF. However, LC, CR and PA were found to be statistically equal to the treatment without AMF. In agave plants inoculated with the EH, EL, AD, and $\mathrm{BN}$ consortia, the increase in total dry weight was greater than $2000 \%$ (Figure 4A). The total dry biomass in agaves without AMF reached an average of just five grams at the end of the trial. 
The mycorrhizal colonization percentages found in the roots of agaves varied significantly, ranging from 14 to $45 \%$ in the different AMF inocula evaluated. The INIFAP $^{\circledR}$ inoculum had the lowest value, though it proved to be statistically similar to that obtained with the EL consortium, which had $40 \%$ colonization. The CM consortium had the highest colonization percentage with almost $46 \%$, being three times more than that obtained with the INIFAP inoculum (Figure 4B).
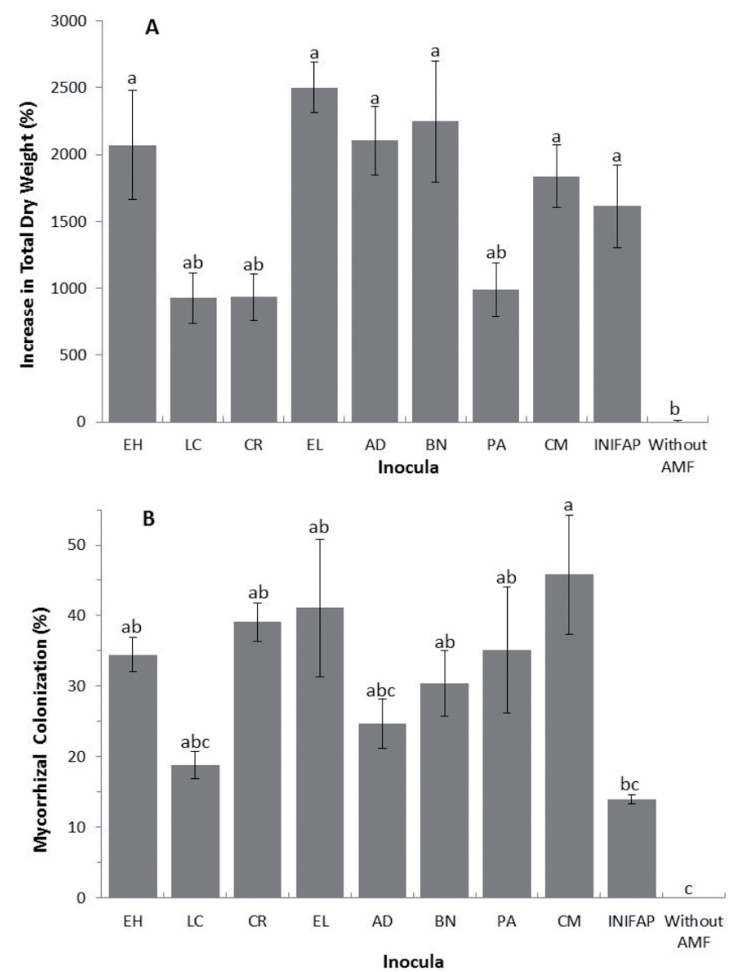

Figure 4. Increase in total dry weight on Agave inaequidens plants inoculated with different AMF respect to plants without AMF (A) and root colonization percentages (B) at 300 days after inoculation. EH, El Huichazal; CR, Carlos Rojas; AD, Agua Dulce; PA, Paso Ancho; LC, Las Campesinas; EL, El Limón; BN, Barranca de las Nueces; CM, Cerro del Metate. Columns with the same letter are statistically equals (Tukey, $p \leq 0.05$ ).
The mycorrhizal dependence of the agave plants turned out to be $70 \%$ higher among the different AMF inocula; however, no statistical difference was found among them. In agaves inoculated with the EL consortium, the relative mycorrhizal dependency rate reached values higher than $95 \%$ (Table 1). These high values indicate that this plant has a strong dependence on mycorrhizal symbiosis, at least during its early stages of growth, which is reflected in the greater growth of inoculated plants compared to noninoculated ones (Figure 5).

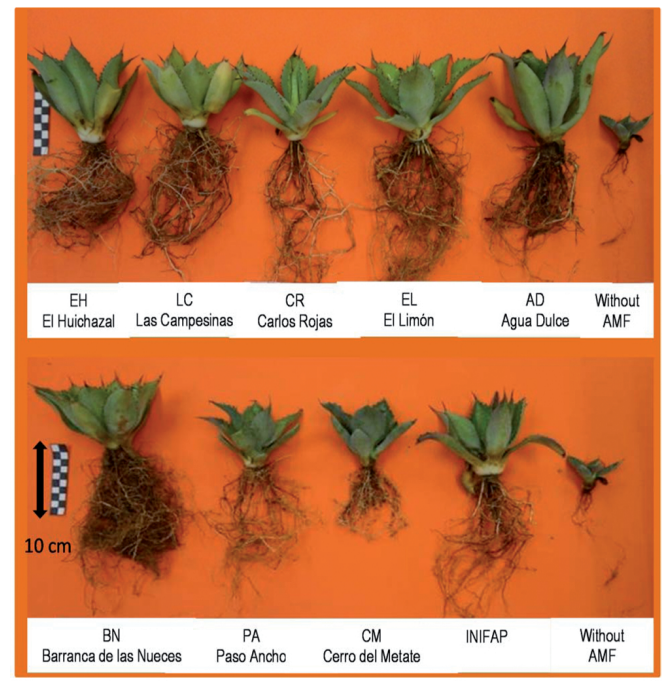

Figure 5. Aspect of Agave inaequidens plants inoculated whit different $\mathrm{AMF}$ at the end of the trial.

The plant quality index which indicates plant vigor (the higher the index value the greater the vigor) showed that, AMF-inoculated plants had differences in quality in the agave plants, according to the parameters used to calculate it. The native EH consortium produced the best quality agave plants, being almost three times higher than plants inoculated with the commercial INIFAP consortium and 80 times higher than plants without AMF. Plants without AMF had 
the lowest plant quality, nearly 20 and 35 times lower than the level obtained with the native CR consortium and the commercial INIFAP one, respectively (Table 1).The values obtained with this index show the high mycorrhizal dependency of Agave inaequidens plants to achieve greater vigor, which could be very useful when using these consortia in propagation programs and their subsequent transplant to the field.

\section{Discussion}

The use of arbuscular mycorrhizal fungi as plant growth promoters has been extensively studied in several plant species (Smith and Smith, 2011), utilizing either a single species (monospecific inocula, which can be commercial or native) or native or selected consortia. Likewise, there are reports concerning CAM plants such as Ferocactus acanthode, Opuntiaficusindica (Cui and Nobel, 1992), Opuntia albicarpa (Estrada-Luna and Davies, 2008), etc. In particular with agavaceas, there are reports with $A$. deserti (Cui and Nobel, 1992), A. angustifolia (Robles-Martínez etal., 2013) and A. tequilana (Pimienta-Barrios et al., 2009; Ruiz et al., 2011), among others. In most of these studies, however, they use either a single species of AMF or native consortia extracted from soils not necessarily from the rhizosphere of the crops where they were evaluated. In our case, despite using consortia from the rhizosphere of Agave cupreata, in the same places where it was sampled, there are also Agave inaequidens plants growing together (Martínez-Castro et al., 2015). On the other hand, the response variables evaluated in this research have already been considered as agave growth indicators due to the effect of inoculation with $\mathrm{AMF}$ or to other factors in different studies (Crespo-González et al.,2013; Yescas-Arreola et al., 2016). This study generally showed that by the end of the trial (300 dai) the agaves inoculated with an AMF consortium orin the monosporic treatment sig- nificantly increased their growth relative to the agaves where the symbiont was not applied (Figure 5).

Thus, agave leaf production and height were favored by inoculation with native AMF, exceeding by more than four times the number of leaves and height of the plants without AMF. Similar results have been reported in other plant species (Quiñones Aguilar et al., 2014; 2015; Reyes Tena et al., 2015). However, Robles-Martínezetal. (2013),working with tillers and bulbils of Agave angustifolia inoculated with native AMF consortia, found no increase in the number of unfolded leaves, and nor did Ruiz et al. (2011) in in vitro A. Tequilana plants inoculated with $G$. intraradices or Pimienta-Barrios et al. (2009) in A. tequilana plants inoculated with $G$. intraradices and G. fasciculatum. The fact of not seeing the effect of inoculation on agaves may be due to the origin of the seedling, as they spend their energy differently, some using it to increase their number of leaves, height or biomass production (Robles-Martínez et al., 2013). Since seedlings obtained from seed were used in this study, it is likely that they invest their metabolic resources in general growth, as inoculated agaves significantly increased their biomass. Robles-Martínez et al. (2013) found that $A$. angustifolia plants inoculated with Glomus intraradices or native AMF consortia significantly increased foliage dry weight with respect to non-inoculated plants. In this study, increases in dry matter were more than 20 times greater than those in non-inoculated plants. On the other hand, there are also reports where inoculation with AMF has not been positive; Ruiz et al. (2011) found that in vitro A. Tequilana plants inoculated with $G$. intraradicess howed no significant differences in fresh and dry weight compared to non-inoculated plants at 263 days after inoculation. On the other hand,the lack of a positive effect may be due to the species composition of the native consortia or to the inoculation of a particular AMF species, as well as the response with each host (Khade and Rodrigues, 
2008; Camprubi et al., 2011). Smith and Smith (2012) suggest that the little or no effect of AMF on plant growth is due to a deficiency of phosphorus in the plants, owing to a reduction in the levels of uptake by the roots, which cannot be sufficiently offset by the low colonization percentage of the roots (Grace et al., 2009). This could be happening in the treatment without inoculation, where the lowest growth of agaves was observed.

Regarding root volume, it is known to be an important element in mycorrhizal plants (Aguín et al., 2004). In this study, root length was found to increase in AMFinoculated plants, but not to a statistically significant degree; on the other hand, root volume increased more than six fold compared to non-inoculated plants (Tukey, $p \leq 0.05$ ). The overall growth increase in inoculated agaves could be due to better nutrient and water uptake, facilitated by the increase in root volume caused by the mycorrhizal symbiosis (Smith and Read, 1997; Quiñones-Aguilar et al., 2015).

Similarly, inoculated plants are known to have a higher photosynthetic rate (Manjarrez-Martínez et al., 1999), which brings with it plants of greater size and weight. Cui and Nobel (1992) showed greater efficiency in $\mathrm{CO}_{2}$ uptake in AMF-inoculated Agave deserti plants.Pimienta-Barrios et al. 2009 report that Agave tequilana plants inoculated with native species of mycorrhizal fungi significantly increased photosynthesis compared to the control. They also found a positive correlation between mycorrhizal colonization and growth of agaves. In this study in the consortia where the highest colonization percentages were obtained was also where the highest values of the growth variables evaluated were reached. The mycorrhization percentages obtained in this work are the first reported for this species of agave and are similar to those reported in other agaves under greenhouse conditions. Robles-Martínez et al. (2013) found 32\% colonization in Agave angustifolia. In Agave deserti there are reports of up to $64 \%$ colonization (Cui and Nobel 1992) and in Agave tequilana up to $90 \%$ under greenhouse conditions (Pimienta-Barrios et al., 2009).

Another possible cause of the increased growth of agaves inoculated with native consortia is the propagation mode of the consortia evaluated (trap pots). It is likely that while AMF spores are propagated, other beneficial organisms such as plant growth promoting rhizobacteria multiply and interact positively to promote agave growth (Azcón-Aguilar and Barea, 2015). De La Torre-Ruiz et al. (2016), working with Agave americana inoculated with Rhizobium daejeonense, Acinetobacter calcoaceticus and Pseudomonas mosselii, found a significant effect $(p<0.05)$ on growth and sugar content. Ruiz et al. (2011), working with Agave tequilana seedlings coinoculated with Glomus intraradices and Gluconoacetobacter diazotrophicus, obtained greater dry weight. In our case, this positive effect of the AMF-rhizobacteria interaction could occur in the treatments with native innocula, but would be unlikely to occur in plants without AMF because the growth medium was previously sterilized or in the treatment with monosporic INIFAP inoculum.

On the other hand, in the treatment with the INIFAP inoculum, despite having obtained a low colonization percentage $(10 \%)$, it was not reflected in decreasedagave growth, which could indicate an effectiveness of this AMF species in agave plants. It is known that this AMF species has high efficiency in promoting growth of the host plant (Robles, 1999). It is also likely that this species of agave has a preference for this species of AMF. Hernández-Morales et al. (2014) reported that the dominant genus of mycorrhizal fungi in the rhizosphere of Agave potatorum was Glomus. Ochoa-Meza et al. (2009) in Agave angustifolia found 32 morphotypes of AMF spores in the plant's rhizosphere, of which 17 were of the genus Glomus. Of the native consortia evaluated in this work, all contained in their composition at least one species of the genus 
Glomus; however, the colonization percentage in the consortia was higher than that found in the monosporic inoculum. This may indicate that the Agave inaequidens root is being colonized by more than one species of AMF, which helps promote plant growth.

On the other hand, the fact of finding a difference in promoting growth among the different native inocula is probably due to the origin and composition of AMF species that made up each inoculum (RincónEnríquezet al., 2012; Reyes-Tena et al., 2015). The consortia with the greatest effect on plant growth were $\mathrm{EL}, \mathrm{EH}, \mathrm{AD}$ and $\mathrm{BN}$, which in general in most of the evaluated variables were found to be statistically equal. However, when the Dickson index was calculated, it was the EH consortium which obtained the best plant quality, widely outperforming the others and by more than 80 times the agaves without AMF. There is usually a better response in plant growth when native rather than exotic microorganisms are used (Pérez-Solís, 2001), as well as consortia composed of several species rather than one (Bashan et al., 2000). Van del Heijden et al. (1998) and Klironomos et al. (2000) mention that the beneficial effect of mycorrhizal fungi in promoting plant growth appears to be defined by the richness of species and the origin of their isolate.

\section{Conclusion}

A promoter and differential effect on growth of Agave inaequidens seedlings due to inoculation with native AMF consortia was found. Agave inaequidens showed a high mycorrhizal dependency and it is likely being colonized by more than one species of AMF. The colonization percentages found were similar to those reported in other species of agave under greenhouse conditions and it is likely that this is the firstpaper where these percentages as well as the effect of inoculation with AMF in promoting growth in this species are reported.Using AMF could be an advisable practice for sustainable production of Agave inaequidens plants; however, it is necessary to continue studying the effect of native consortia on established plantations and evaluate the behavior of nursery inoculated plants when transplanted to the field in order to be widely recommended.

\section{Acknowledgements}

The authors are grateful to FOMIX MichoacánCONACYT (MICH-2010-C01-148208) and Coordinación de la Investigación Científica (CIC) of UMSNH for funding this project. Cristina Montoya thanks CONACYT for granting her a scholarship to study her master's degree and Dr. Gabriel Rincón for having served as co-director of her thesis.

\section{References}

Azcón-Aguilar C., Barea, J. M. 2015. Nutrient cycling in the mycorrhizosphere. J. Soil Sci. Plant Nutr. 15 (2), 372-396.

Aguín, O., Mansilla, J. P., Vilariño, A., Sainz, M. J. 2004. Effects of mycorrhizal inoculation on root morphology and nursery production of three grapevine rootstocks. Am. J. Enol. Vitic. 51, 108111.

Bashan, Y., Davis, E.A., Carrillo-Garcia, A., Linderman, R.G. 2000. Assessment of VA mycorrhizal inoculum potential in relation to the establishment of cactus seedlings under mesquite nurse-trees in the Sonoran desert. Applied Soil Ecology. 14, 165-176.

Camprubi, A., Estaun, V., Calvet, C. 2011. Greenhouse inoculation of psammophilic plant species with arbuscular mycorrhiza fungi to improve survival and early growth.European Journal of Soil Biology. 47, 194-197. 
Carballar-Hernández, S., Palma-Cruz, F.J., Hernández-Cuevas, L., Robles. C. 2013. Arbuscular mycorrhizal potential and mycorrhizal fungi diversity associated with Agave potatorum Zucc. in Oaxaca, Mexico. Ecol Res. 28, 217-226.

Carreón-Abud, Y., Vega-Fraga, M., Gavito, M. E. 2015. Interaction of arbuscular mycorrhizal inoculants and chicken manure in avocado rootstock production. J. Soil Sci. Plant Nutr. 15 (4), $867-$ 881.

Cui, M., Nobel, P.S. 1992. Nutrient status, water uptake and gas exchange for three desert succulents infected with mycorrhizal fungi. New Phytol. 122, 643-649.

Crespo-González, M., González-Eguiarte, R., Rodríguez-Macías, D. R., Rendón Salcido, R., del Real Laborde, L.A., Ignacio, J., Torres Morán, J.P. 2013. Evaluación de la composta de bagazo de agave como componente de sustratos para producir plántulas de agave azul tequilero. Revista Mexicana de Ciencias Agrícolas. 4, 1161-1173.

De La Torre-Ruiz, N., Ruiz-Valdiviezo, V.M., RincónMolina, C.I., Rodríguez-Mendiola, M., AriasCastro, C., Gutiérrez-Miceli, F. A., PalomequeDominguez, H., Rincón-Rosales, R. 2016.Effect of plant growth-promoting bacteria on the growth and fructan production of Agave Americana L. Brasilian Journal of Microbiology. 47, 587-596.

Dickson, A., Leaf, A.L., Hosnerm, J. F. 1960. Quality appraisal of white spruce and white pine seedling stock in nurseries.For. Chron. 36, 10-13.

Estrada-Luna, A.A., Davies, F.T. 2008. Nutrient status and growth of micropropagated prickly-pear cactus (Opuntia albicarpa Scheinvar cv. "Reyna") plantlets colonized with three-selected endomycorrhiza isolates. In: N. M. Montaño-Arias, S. L. Camargo-Ricalde, R. García-Sánchez, A. Monroy-Ata (eds). Arbuscular mycorrhizae in arid and semi-aridecosystems. Mundi Prensa, México, pp: 204-215
Figueredo, C.J., Casas, A., González-Rodríguez, A., Nassar, J.M., Colunga-GarcíaMarín, P., RochaRamírez, V. 2015. Genetic structure of coexisting wild and managed agave populations: implications for the evolution of plants under domestication. AoB PLANTS 7, plv114; doi:10.1093/ aobpla/plv114

Gavito, M., Varela, L. 1995. Response of "criollo" maize to single and mixed species inocula of arbuscular mycorrhizal fungi.Plant and Soil. 176, 101-105.

Grace, E.J., Cotsaftis, O., Tester, M.M., Smith, F A., Smith, S. E. 2009. Arbuscular mycorrhizal inhibition of growth in barley cannot be attributed to extent of colonization, fungal phosphorus uptake or effects on expression of plant phosphate transporter genes. New Phytol. 181, 938-949.

Hernández-Morales, J.L., López-Sánchez, C. PalmaCruz, F. 2014. Caracterización morfológica de micorriza arbuscular asociada a Agave potatorum Zucc. con potencial de uso agronómico. Revista Mexicana de Agroecosistemas. 1, 82-93.

Hodge, A. 2000. Microbial ecology of the arbuscular mycorrhiza.FEMS. Microbiology Ecology. 32, 91-96.

Khade, S.W., Rodrigues, B.F. 2008. Ecology of arbuscular mycorrhizal fungi associated with Carica papaya L. in agro-based ecosystem of Goa, India. Trop. Subtrop. Agroecosyst. 8, 265-278.

Manjarrez-Martínez, M.J., Ferrera-Cerrato., R., González-Chávez, M.C. 1999. Effect of Vermicompost and Mycorrhizal Fungi on Growth and Photosynthetic Rate of Chili.Terra. 17, 9-15.

Klironomos, J.N., Mccune, J., Hart, M., Neville, J. 2000. The influence of arbuscular mycorrhizae on the relationships between plant diversity and productivity.Ecology Letters 3, 37-141. 
Martínez-Castro, L.E., Martínez-Palacios, A., Sánchez-Vargas, N. M., Lobitte, P., Nápoles-Alvarez, C.R., Martínez-Palacios, O., Villegas, J., Martínez-Avalos, J.G., Golubov, J. 2015. Poblaciones silvestres de maguey chino (Agave cupreata) en el Estado de Michoacán. In: A. Martínez-Palacios, J.L. Morales-García, S. Guillén-Rodríguez (eds). Aspectos sobre el manejo y la conservación de Agaves Mezcaleros en Michoacán, Consejo Estatal de Ciencia, Tecnología e Innovación de Michoacán, Morelia, Michoacán, México, pp: 167175.

Mcgonigle, T., Miller, M., Evans, D., Fairchild, G., Swan, J. 1990. A new method wich gives and objective measure of colonization of roots by vesicular-arbuscular mycorrhizal fungi. New Phytol.115, 495-501.

Ochoa-Meza, A., Esqueda, M., Fernández-Valle, R., Herrera-Peraza, R. 2009. Variación estacional de hongos micorrízicos arbusculares asociados con Agave angustifolia Haw. En la sierra sonorense, México. Rev. Fitotec. Mex. 32,189-199.

Pérez-Solís, E. 2001. Prospección y aplicación de micorrizas en especies vegetales autóctonas del matorral, para favorecer la revegetación de ecosistemas mediterráneos degradados. Ph. D. Thesis, Universidad de Granada. Granada, España. 156 p.

Phillips, J., Hayman, D. 1970. Improved procedures for clearing roots and staining parasitic and vesicular-arbuscular mycorrhizal fungi for rapid assessment of infection. Transactions of the British Mycological Society. 55, 158-160.

Pimienta-Barrios, E., Zañudo-Hernandez, J., LópezAlcocer, E. 2009. Efecto de las micorrizas arbusculares en el crecimiento, fotosíntesis y anatomía foliar de plantas jóvenes de Agave tequilana. Acta Botanica Mexicana. 89, 63-78.
Plenchette, C., Fortin, J.A., Furlan, V. 1983. Growth response of several plant species to mycorrhiza under field conditions.Plant Soil. 70, 191-209.

Quiñones-Aguilar, E. E., López-Pérez, L., RincónEnríquez, G. 2014. Growth dynamics of papaya due to mycorrhizal inoculation and phosphorous fertilization.Revista Chapingo Serie Horticultura. 20, 223-237.

Quiñones-Aguilar, E.E., Rincón-Enríquez, G., Hernández-Cuevas, L.V., López-Pérez, L. 2015. Influence of Arbuscular Mycorrhizal Fungi and Nitrogen Concentrations on Carica papaya Plant Growth. Int. J. Agric. Biol. 17, 119-126.

Reyes-Tena, A., López-Pérez, L., Quiñones-Aguilar, E. E., Rincón-Enríquez, G. 2015. Evaluación de consorcios micorrícicos arbusculares en el crecimiento vegetal de plantas de maíz, chile y frijol. Biológicas. 17, 35-42.

Rillig, M. C., Mummey, D. L. 2006. Mycorrhizas and soil structure.New Phytol. 171, 141-153.

Rincón-Enríquez, G., Quiñones-Aguilar, E.E., Montoya-Martínez, A.C., López-Pérez, L., Hernández-Cuevas, L.V. 2012. Diversidad de hongos micorrízicos arbusculares de suelos de Agave cupreataTrel y Berger en Michoacán. In: F. BlancoMacías, A. G. Bravo-Lozano, J. Hernández-Martínez, A. Lara-Herrera, R. Magallanes-Quintanar, S.J. Méndez-Gallegos, R.D. Valdez-Cepeda (eds). Tópicos edafológicos de actualidad. Universidad Autónoma de Zacatecas. Zacatecas, México, pp. 11-15.

Robles, C. 1999. Modificaciones en las propiedades físicas, químicas y biológicas de suelos en respuesta a la actividad de organismos simbióticos y rizosféricos, en el contexto de una agricultura sostenible. Ph. D. Thesis . Universidad Politécnica de Madrid. Madrid, España. 165 p. 
Robles-Martínez, M.L., Robles, C., Rivera-Becerril, F., Ortega-Larrocea, M.P., Pliego- Marín, L. 2013. Inoculación con consorcios nativos de hongos de micorriza arbuscular en Agave angustifolia Haw. Revista Mexicana de Ciencias Agrícolas. 6, 12311240 .

Ruiz, S., Adriano, L., Ovando, I., Navarro, C., Salvador, M. 2011. Biofertilization of micropropagated Agave tequilana: Effect on plant growth and production of hydrolytic Enzymes. African Journal of Biotechnology. 10, 9623-9630.

Smith, S.E., Gianinazzi-Pearson, V. 1988. Physiological interactions between symbionts in vesiculararbuscular mycorrhizal plants.Annual Review of Plant Physiology. 39, 221-244.

Smith, S. E., Read, D. J. 1997. Mycorrhizal symbiosis. Academic Press, San Diego, CA, 800 p.

Smith, A. F., Smith, S.E. 2011. What is the significance of the arbuscular mycorrhizal colonization of many economically important crop plants? Plant Soil. 348, 63-79.
Smith, S.E., Smith, F.A. 2012. Fresh perspectives on the roles of arbuscular mycorrhizal fungi in plant nutrition and growth. Mycologia. 104, 1-13.

Trejo, D., Ferrera-Cerrato, D., García, R., Varela, L., Lara, L., Alarcón A. 2011. Effectiveness of native arbuscular mycorrhizal fungi consortia on coffee plants under greenhouse and field conditions. Revista Chilena de Historia Natural. 84, 23-31.

Van Der Heijdden, M. G.A., Klironomos, J. N.,Ursic, M., Moutoglis, P., Streitwolf-Engel, R., Boller, T., Wiemken, A., Sanders, I. R. 1998. Mycorrizhal fungal diversity determines plant biodiversity, ecosystem variability and productivity. Nature. $396,69-72$.

Yescas-Arreola, E., Gisela V., Campos, Á., Enríquez del Valle, J. R., Velasco-Velasco, V. A., Rodríguez-Ortiz, G., Ruiz-Luna, J. 2016. Acclimation of Agave americana var. Oaxacensis obtained in vitro. Revista Mexicana de Ciencias Agrícolas. 4, 911-922. 